\title{
Excessive distension absorption in patient went through hysteroscopic surgery distended with $5 \%$ mannitol solution : a retrospective study.
}

\author{
Ruowu $\mathrm{Ma}^{1}$, Shuying Feng ${ }^{1}$, and Meiqing Xie ${ }^{1}$ \\ ${ }^{1}$ Sun Yat-Sen Memorial Hospital
}

December 23, 2020

\begin{abstract}
Objective: To estimate the incidence of excessive distension absorption in the patient went through hysteroscopic surgery distended with $5 \%$ mannitol solution, to evaluate the use of $5 \%$ mannitol solution for hysteroscopic surgical procedure specifically and to testify the safe threshold for distension absorption. Design: Retrospective. Setting: Academic medical center. Patients: 10693 patients went through inpatient hysteroscopic surgery distended with $5 \%$ mannitol solution using monopolar electrosurgical instrument from Jan. 2015 to Sep. 2020. Intervention(s): None. This study has been approved by the Ethics Committee of Sun Yat-sen Memorial Hospital. Measurements and Main Results: Fluid deficit more than 1000mL is defined as excessive distension absorption. Incidence of excessive distension absorption in all the inpatient hysteroscopic surgeries is $0.46 \%(49 / 10693)$. It is $2.57 \%(16 / 623)$ in transcervical resection of fibroid (TCRF), $2.36 \%(9 / 381)$ in retained products of conception (RPOC) removal, 1.20\% (6/501) in hysteroscopic uterine septum resection (HSR), 0.53\% (14/2621) in transcervical resections of adhesion (TCRA) while in the severe cases it was $2.34 \%(14 / 598), 0.48 \%(4 / 828)$ in transcervical resection of the endometrium (TCRE). Excessive distension absorption developed within ten minutes in two cases. Twelve of thirty nine patients with fluid deficit under $2500 \mathrm{~mL}$ presented with clinical consequences related to circulation overload. Conclusion: Incidence of excessive distension absorption could be low generally however it would be five times higher in TCRP, RPOC removal and TCRA. Resection by needle electrode may contribute to the excessive distension absorption developed within short time. $30.77 \%$ of the patients could not tolerate the less than $2500 \mathrm{~mL}$ distension absorption.
\end{abstract}

\section{Introduction}

As a minimal invasive surgical approach, hysteroscopy is widely used for intrauterine examination and surgery. Hysteroscopic approach has been irreplaceable for evaluating the cervical canal and uterine cavity, correcting intrauterine malformation and treating intrauterine pathology. Uterine distention by distending media for adequate visualization of the intrauterine cavity is demanded during the procedure. The traditional electrosurgical instrumentation included monopolar radiofrequency $(\mathrm{RF})$ system and bipolar $\mathrm{RF}$ system depending on their different mechanism of electronic current initiation. Despite the advantage of minimal invasive approach and adequate visualization, hysteroscopy could also be complicated with unpleasant conditions such as inflammation, hemorrhage, uterine perforation and fluid overload[1].

Fluid overload is initiated by the excessive absorption of distending media. At the very beginning it was described as female TURP (transurethral resection of prostate) syndrome[2]. Distending media could be classified according to their tonicity, electrolyte content and viscosity. Electrolyte-free distending media is required for monopolar electrosurgical procedure. Excessive absorption of $5 \%$ mannitol solution which is isotonic, electrolyte-poor, low-viscosity could lead to fluid overload along with hyponatremia and hyposmolarity with the potential developing pulmonary edema, congestive heart failure and cerebral edema[3]. When 
hyponatremic encephalopathy develops, menstruant women were supposed 25 times more likely to die or have permanent cerebral damage when compared with either men or postmenopausal women[4].

The maximum fluid deficit for $5 \%$ mannitol was set at $1000 \mathrm{~mL}$ in the ACOG (American College of Obstetricians and Gynecologists) guideline in 2020. In the earlier 2016, BESG/ESGE (British Society For Gynecological Endoscopy/ European Society For Gynecological Endoscopy) defined more than 1000mL hypotonic fluid deficit as threshold to fluid overload. For isotonic distending media the threshold was set at $2500 \mathrm{~mL}$ based on expert opinion [5]. $5 \%$ mannitol solution is isotonic but electrolyte-free. Upper safe threshold for such media should be testified based on clinical data. Even through extensive distension absorption is a well known hysteroscopic complication, due to the variable nomination, definition, multiple choice of distending media and setting of distension pressure, the incidence, clinical presentation, management and prognosis of such complication lack specific description.

\section{Materials and Methods}

We searched the electronic medical record system for potentially eligible records. From Jan. 2015 to Sep. 2020, 10693 inpatient hysteroscopic surgeries including 623 transcervical resections of fibroid (TCRF), 2621 transcervical resections of adhesion (TCRA), 381 hysteroscopic retained product of conception (RPOC) removals, 501 hysteroscopic uterine septum resections (HSR), 828 transcervical resections of the endometrium (TCRE) have been completed in our hospital using monopolar instrument distended with $5 \%$ mannitol solution in our hospital. The inflow pressure was set at $120 \mathrm{mmHg}$ conventionally for adequate intrauterine visualization during the hysteroscopic procedure. All these inpatient surgeries were arranged in the operation theatre under general anesthesia. Fluid deficit more than $1000 \mathrm{~mL}$ is defined as excessive distension absorption[1]. These electrosurgical procedures were performed using standard rigid monopolar resectoscope ( Storz, Germany).

Hysteroscopic scissor, Hysteroscopic Endo Operative System (HEOS), MyoSure Hysteroscpoic Tissue Removal System (MyoSure) and bipolar electrosurgical instrument have been introduced since 2017. Hysteroscopic surgical procedures using these operative instruments were distended with normal saline are not recruited in this retrospective study.

The results are reported as the mean \pm SD. Data were analyzed with SPSS version 25 (IBM, Armonk, NY).

This retrospective study has been approved by the Ethics Committee of Sun Yat-sen Memorial Hospital.

\section{Result(s)}

From Jan. 2015 to Sep. 2020, forty nine patients suffered excessive distention absorption defined more than $1000 \mathrm{~mL}$ fluid deficit. Forty nine cases are including sixteen cases of TCRF, fourteen cases of TCRA all of them were diagnosed severe IUA (European Society for Gynegological Endoscopy Grade[?]III), nine cases of RPOC removal, six cases of HSR and four cases of TCRE. Incidence of the excessive distention absorption is $0.46 \%$ (49/10693) generally, $2.57 \%(16 / 623)$ in TCRF, $2.36 \%$ (9/381) in RPOC removal, $1.20 \%(6 / 501)$ in HSR, $0.53 \%(14 / 2621)$ in TCRA and $2.34 \%(14 / 598)$ in severe IUA cases, $0.48 \%$ (4/828) in TCRE (Table 1).

Ten of these forty nine patients went through laparoscopy combined hysteroscopy, general endotracheal anesthesia was arranged at the beginning of the procedure. Six of the rest thirty nine patients was arranged intravenous anesthesia at the beginning underwent endotracheal intubation in the middle of the surgery in order to manage the respiration and circulation. Fluid deficit was from $1000 \mathrm{~mL}$ to $4500 \mathrm{~mL}$. Two patients were transferred to the intensive care unit due to unsatisfied postoperative oxygenation. Operative time had been recorded. One patient went through HSR developed excessive distention absorption within seven minutes and another patient went through TCRA developed fluid overload with pulmonary edema within ten minutes. The fluid deficits of these two cases were $1500 \mathrm{~mL}$ and $1800 \mathrm{~mL}$ respectively.

Clinical consequences were recorded in eighteen cases that varies from vomiting, nausea to cardiovascular disturbance such as hypoxemia, tachycardia, bradycardia, hypotension, pulmonary edema and laryngeal edema. 
(Table 2). Postoperative and intraoperative hyponatremia were detected in all these patients from $95 \mathrm{mmol} / \mathrm{L}$ to $129 \mathrm{mmol} / \mathrm{L}$ while the preoperative serum sodium were within normal range from $136-142 \mathrm{mmol} / \mathrm{L}$. Three patients were recorded severe hyponatremia with serum sodium lower than $100 \mathrm{mmol} / \mathrm{L}$. All of these three patients presented with cardiovascular disturbance such as bradycardia and hypotension. When the serum sodium was ranging from 100 to $110 \mathrm{mmol} / \mathrm{L}, 50 \%$ (3/6) of them were complicated with clinical consequences. When the serum sodium was between 110 to $120 \mathrm{mmol} / \mathrm{L}, 36.36 \%(4 / 11)$ developed clinical consequences. And the incidence of clinical consequence is $27.59 \%(8 / 29)$ when the serum sodium was between 120 to $130 \mathrm{mmol} / \mathrm{L}($ table 3$)$.

All the clinical consequences and laboratory abnormalities were corrected before the patients' discharge. No sign or symptom of hyponatremic encephalopathy was detected in all the patients in the postoperative follow up.

\section{Discussion}

The incidence of fluid overload seems low. In Jansen FW' s study in 2000, five cases were recorded fluid overload defined as more than $1500 \mathrm{ml}$ distention absorption with clinical consequences, the reported incidence is $0.2 \%$ [6]. In Aydeniz B and his colleagues' multicenter study in 2002, thirteen cases were recorded fluid overload syndrome defined as hyponatremia caused by at least $2000 \mathrm{~mL}$ hypotonic distension absorption. The reported incidence is $0.06 \%$ [7]. Based on the 2020 ACOG guideline, in our study the incidence of excessive distension absorption is $0.46 \%$ (49/10693). In certain kind treatment such as TCRP, RPOC removal and adhesiolysis in severe IUA cases, it is 5 times higher. Incidence of fluid overload would be low and variable due to different definition or diagnostic criteria , the excessive distension absorption should call attention.

Distension absorption is pressure dependent[8]. It was illustrated in a series of myomectomies, the distension absorption during the procedure depends on the degree of myometrial penetration also[9]. From the first 250 endometrial resections experience the distension absorption seems time dependent and it was also influenced by the endometrial preparation and tubal patency [10]. Using vasopressin during hysteroscopic myomectomy had been shown to decrease the distension absorption [11][12]. In Colacurci N's study comparing two hysteroscopic treatments of uterine septum, the uterine cavity was distended with sorbitol-mannitol in resectoscopic metroplasty at the pressure of 60 to $90 \mathrm{~mm} \mathrm{Hg}$. In the small-diameter hysteroscopy group the uterus was distended with normal saline at the pressure of 90 to $100 \mathrm{mmHg}$. The fluid deficit in the group distended with sorbitol-mannitol was $486.4+-169.9 \mathrm{~mL}$. In the small-diameter hysteroscopy group distended with saline the fluid deficit was $222.1+-104.9 \mathrm{~mL}$. Operative time was significantly longer in the first group[13]. It seems that the prolonged operative time compensated the lower distending pressure influence on distension absorption.

Fourteen patients underwent TCRA were recorded excessive distension absorption. It was probably resulted from myometrial integrity damage during the procedure. Especially in the severe cases majority of the endometrium was damaged and replaced by fibrous scar tissue. In our study, one patient went through HSR developed excessive absorption within 7 minutes and another one went through TCRA developed excessive distention absorption within 10 minutes. The hysteroscopic surgical procedures in them were performed by monopolar needle electrode. Mechanical dissection is free from thermal damage which may exist in the electrosurgical treatment. Adhesiolysis using cold scissor may also contribute to a better postoperative AFS score and pregnancy outcome [14]. Hysteroscopic scissor (cold scissor) has been introduced to this center since 2017. No cases of excessive distension absorption were recorded in the IUA dissections using cold scissor yet. Without electronic energy the scissor does not have any hemostasis function. When the myometrial was broken, the bleeding would be more likely to be detected by the operator. The surgical procedure would be adjusted to avoid advanced myometrial damage. Since distension absorption was supposed to depend on the degree of myometrial penetration in the myomectomy series study[9]. The surgical protocol adjustment would possibly help to avoid advanced myometrial penetration and decrease distension absorption. Since mechanical dissection using cold scissor does not require electrolyte-poor distending media which would permit a larger fluid deficit[1]. The operator needs to improve surgical proficiency in order to complete the 
surgical procedure by new instrument within the time no longer than the old way. That's how will the new technology benefit the patient.

Depends on the operator's proficiency and the intrauterine visualization not all of the hysteroscopic procedure would be completed when the fluid deficit reach the threshold. If fluid deficit of $1000 \mathrm{~mL}$ was set as a stopping point for the hysteroscopic procedure, the incidence of excessive distension absorption would be zero. But in our study we find that when the fluid deficit was between $1000-1500 \mathrm{~mL}, 77.78 \%(14 / 18)$ patients seems tolerable to the excessive mannitol absorption, free from clinical disturbance except for decreasing serum sodium from 124.8 to $129.4 \mathrm{mmol} / \mathrm{L}$. When the fluid deficit was between $1500-2500 \mathrm{~mL}, 38.10 \%(8 / 21)$ may suffer from various clinical consequences,19.05\% (4/21) of them developed pulmonary edema. When the fluid deficit was higher than $2500 \mathrm{~mL}, 20 \%(2 / 10)$ of these patients required intensive care unit treatment, $60 \%$ $(6 / 10)$ of them presented with clinical consequences. For health adult $2500 \mathrm{~mL}$ was set as the maximal fluid deficit for electrolyte-containing isotonic distending solution based on the expert opinion[1]. But in our study $30.77 \%$ (12/39) of the patients with fluid deficit from 1000 to $2500 \mathrm{~mL}$ presented with clinical sign or symptom related to fluid overload other than hyponatremia. $10.26 \%$ (4/39) of them developed pulmonary edema the fluid deficits were $1700 \mathrm{~mL}, 1800 \mathrm{~mL}, 2160 \mathrm{~mL}$ and $2170 \mathrm{~mL}$. No patients developed pulmonary edema when the fluid deficit was within $1500 \mathrm{~mL}$. Since all the clinical consequences were related to circulation overload other than hyponatremia, this finding should also call attention to the hysteroscopic surgery using normal saline as distending media when the fluid deficit exceeding $1500 \mathrm{~mL}$.

Major disadvantage of $5 \%$ mannitol solution absorption seems to be the risk of developing hyponatremia and hyposmolarity besides circulation overload when compared with electrolyte-containing solution. The serious sequelae of hyponatremia included confusion, seizures, cerebral edema and death[15]. Since all the hysteroscopic surgeries in our study were performed under general anesthesia, no seizure or confusion were detected during the surgery. The intervention was initiated immediately by the anesthesiologist once the fluid overload was detected. Three patients developed severe hyponatremia with serum sodium lower than $100 \mathrm{mmol} / \mathrm{L}$, the serum sodium was corrected higher than $130 \mathrm{mmol} / \mathrm{L}$ within four hours. No sign or symptom of hyponatremic encephalopathy was detected in them on the day of surgery after anesthetic resuscitation and the day after surgery before leaving the hospital. No sign or symptom of hyponatremic encephalopathy sequelae was reported in their one month later postoperative follow-up also.

Treating RPOC through hysteroscopic approach seems to have a high rate of complete removal of RPOC in one step and no detrimental effect on reproductive outcome[16][17]. Complications such as bleeding, uterine perforation, pelvic inflammation were reported [18]. One of one hundred fifty nine patients $(0.63 \%$ 1/159)went through hysteroscopic removal of RPOC in Abraham's study developed pulmonary edema. The hysteroscopic percedure in Abraham's study was performed using bipolar resectoscope. Uterus was distended with normal saline at a pressure of 90 to $110 \mathrm{mmHg}$ [19]. In our study we also find that excessive distension absorption would develop in hysteroscopic procedure treating RPOC using monopolar instrument when the uterus was distended with isotonic electrolyte-poor solution. The interval to the termination of last pregnancy were from eighteen days to twelve weeks. The incidence of excessive distension absorption in treating RPOC through hysteroscopic approach in this study is $2.36 \%(9 / 381) .0 .52 \%(2 / 381)$ of these patients developed pulmonary edema. The fluid deficits in these two cases were $1700 \mathrm{~mL}$ and $3800 \mathrm{~mL}$ respectively. Incidence of pulmonary edema was not increased in this study when the uterus was distended with mannitol solution.

Circulation overload is a universal consequence of excessive distension absorption regardless the different choice of distending media. The incidence of clinical consequences increase along with the fluid deficit. In certain kind treatment the operator should be aware of that the incidence would be five times higher. And the excessive distension absorption could develop within 7 minutes when the procedure was performed using needle electrode.

\section{Limitation}

This is a retrospective study. Since all the inpatient surgeries were performed under general anesthesia, clinical symptoms related to hyponatremia such as confusion and seizure would probably not be detected 
before anesthetic resuscitation. In the laparoscopy combined hysteroscopy procedures, time of hysteroscopic procedure was not recorded separately.

\section{Acknowledgments}

We thank all of the patients who seek hysteroscopic treatment in our hospital. We thank Chunling Chen and Xiaoqing Lin for their assistance in electronic medical records reviewing.

\section{Disclosure of interests}

We declare that we have no conflict of financial, personal, political, intellectual or religious interests.

\section{Contribution to Authorship}

R.W.M. collected, analyzed the data and draft the manuscript. S.Y.F. helped to revise the manuscript. M.Q.X. designed the study and revised the manuscript. All of the authors critically revised the manuscript, contributed to the submission and approved the version to be published.

\section{Details of Ethics Approval}

The study was approved by the Ethics Committee of Sun Yat-sen Memorial Hospital on October 26, 2020 (Reference No. SYSEC-KY-KS-2020-169).

\section{Funding}

This study has not been supported by any funding.

\section{Reference}

1. The use of hysteroscopy for the diagnosis and treatment of intrauterine pathology: ACOG Committee Opinion, Number 800.Obstet Gynecol.2020;135:138-148.

2. Russell Macdonald, Albert Singer.Endometrial resection and fluid absorption.Lancet.1989;2(8676):1387-1388.

3. AAGL practice report:practice guidelines for the management of hysteroscopic distending media (replaces hysteroscopic fluid monitoring guidelines.J Am Assoc Gynecol Laparosc. 2000;7:167-168.).J Minim Invasive Gynecol.2013;20:137-148.

4. Ayus JC, Wheeler JM, Arieff AI. Postoperative hyponatremic encephalopathy in menstruant women. Ann Intern Med. 1992;117(11):891-897.

5. Umranikar S, Clark TJ, Saridogan E, et al. BSGE/ESGE guideline on management of fluid distension media in operative hysteroscopy. Gynecol Surg.2016;13(4):289-303.

6. Jansen FW, Vredevoogd CB, van Ulzen K, Hermans J, Trimbos JB, Trimbos-Kemper TC. Complications of hysteroscopy: a prospective, multicenter study.Obstet Gynecol.2000;96:266-270.

7. Aydeniz B, Gruber IV, Schauf B, Kurek R, Meyer A, Wallwiener D.A multicenter survey of complications associated with 21,676 operative hysteroscopies. Eur J Obstet Gynecol Reprod Biol. 2002;104:160-164.

8. Madsen PO, Naber KG.The importance of pressure in the prostatic fossa and absorption of irrigation fluid during transurethral resection of the prostate.J Urol.1973;109:447-452.

9. Emanuel MH, Hart A, Wamsteker K, Lammes F.An analysis of fluid loss during transcervical resection of submucous myomas.Fertil Steril.1997;68:881-886.

10. Magos AL, Baumann R, Lockwood GM, et al. Experience with the first 250 endometrial resections for menorrhagia.Lancet.1991,337(8749):1074-1078.

11. Wong AS, Cheung CW, Yeung SW, Fan HL, Leung TY, Sahota DS. Transcervical intralesional vasopressin injection compared with placebo in hysteroscopic myomectomy: a randomized controlled trial. Obstet Gynecol 2014;124:897-903.

12. Phillips DR, Nathanson HG, Milim SJ, Haselkorn JS, Khapra A, Ross PL. The effect of dilute vasopressin solution on blood loss during operative hysteroscopy: a randomized controlled trial. Obstet Gynecol.1996;88:761-766. 
13. Colacurci N, De Franciscis P, Mollo A, De Placido G, et al. Small-diameter hysteroscopy with Versapoint versus resectoscopy with a unipolar knife for the treatment of septate uterus: a prospective randomized study.J Minim Invasive Gynecol.2007;14(5):622-627

14. Zhao X, Zhang A, Gao B, Xu D, et al. Cold scissors ploughing technique in hysteroscopic adhesiolysis: a comparative study. Ann Transl Med. 2020;8(4):50-58.

15. Moritz ML, Ayus JC. Water water everywhere: standardizing postoperative fluid therapy with $0.9 \%$ normal saline. Anesth Analg.2010;110:293-295.

16. Vitale SG, Parry JP, Carugno J, De Franciscis P. Surgical and reproductive outcomes after hysteroscopic removal of retained products of conception: a systematic review and meta-analysis. J Minim Invasive Gynecol.2020.Nov 06.

17. van Wessel S, Coryn, N, van Vliet H, Hamerlynck T. Reproductive and obstetric outcomes after hysteroscopic removal of retained products of conception. J Minim Invasive Gynecol.2020;27(4):840846.

18. .Smorgick N, Ayashi N, Levinsohn-Tavor O, Maymon R. Postpartum retained products of conception: retrospective analysis of the association with third stage of labor placental complications. Eur J Obstet Gynecol Reprod Biol.2019;234:108-111

19. Golan A, Dishi M, Shalev A, Sagiv R. Operative hysteroscopy to remove retained products of conception: novel treatment of an old problem. J Minim Invasive Gynecol.2011;18(1):100-103

Table 1. Demographic characteristics of the excessive distension absorption cases

\begin{tabular}{|c|c|c|c|c|c|}
\hline $\begin{array}{l}\text { Type of } \\
\text { procedure }\end{array}$ & TCRF & TCRA & $\begin{array}{l}\text { RPOC } \\
\text { removal }\end{array}$ & HSR & TCRE \\
\hline $\begin{array}{l}\text { Incidence of } \\
\text { excessive } \\
\text { absorption }\end{array}$ & $2.57 \%(16 / 623)$ & $0.53 \%(14 / 2621)$ & $2.36 \%(9 / 381)$ & $1.20 \%(6 / 501)$ & $0.48 \%(4 / 828)$ \\
\hline Age (year) & $38.69 \pm 9.36$ & $29.21 \pm 5.51$ & $31.78 \pm 5.51$ & $29.00 \pm 6.54$ & $42.50 \pm 3.00$ \\
\hline $\begin{array}{l}\text { Bodyweight } \\
(\mathrm{kg})\end{array}$ & $57.38 \pm 9.81$ & $54.12 \pm 9.18$ & $53.00 \pm 6.15$ & $48.83 \pm 4.54$ & $52.38 \pm 6.02$ \\
\hline $\begin{array}{l}\text { Preoperatove } \\
\text { systolic pressure } \\
(\mathrm{mmHg})\end{array}$ & $114.50 \pm 12.49$ & $111.57 \pm 10.05$ & $101.44 \pm 12.71$ & $109.83 \pm 9.41$ & $106.00 \pm 3.46$ \\
\hline $\begin{array}{l}\text { Preoperatove } \\
\text { diastolic pressure } \\
(\mathrm{mmHg})\end{array}$ & $76.13 \pm 8.15$ & $74.71 \pm 8.53$ & $67.67 \pm 4.87$ & $71.67 \pm 9.85$ & $72.00 \pm 2.94$ \\
\hline $\begin{array}{l}\text { Menstrual } \\
\text { cycle(day) }\end{array}$ & $28.50 \pm 4.43$ & $28.93 \pm 2.37$ & $28.56 \pm 3.09$ & $32.17 \pm 6.34$ & $32.25 \pm 8.54$ \\
\hline $\begin{array}{l}\text { Mestruation } \\
\text { duration (day) }\end{array}$ & $5.69 \pm 1.92$ & $6.07 \pm 1.33$ & $5.56 \pm 1.67$ & $5.67 \pm 1.21$ & $9.50 \pm 7.05$ \\
\hline $\begin{array}{l}\text { Heart rate } \\
(\mathrm{bpm})\end{array}$ & $82.06 \pm 11.64$ & $76.50 \pm 12.06$ & $85.22 \pm 8.89$ & $77.83 \pm 9.39$ & $86.75 \pm 9.03$ \\
\hline Gravida & $1.69 \pm 1.49$ & $2.79 \pm 1.76$ & $2.78 \pm 1.39$ & $2.33 \pm 3.86$ & $2.75 \pm 1.50$ \\
\hline Parity & $0.81 \pm 0.91$ & $0.71 \pm 0.91$ & $0.67 \pm 1.00$ & $0.5 \pm 0.84$ & $0.75 \pm 0.50$ \\
\hline $\begin{array}{l}\text { Preoperative } \\
\text { serum sodium } \\
(\mathrm{mmol} / \mathrm{L})\end{array}$ & $139.19 \pm 1.38$ & $138.74 \pm 1.01$ & $139.20 \pm 1.08$ & $138.17 \pm 0.98$ & $138.75 \pm 2.06$ \\
\hline $\begin{array}{l}\text { Intraoperative } \\
\text { serum sodium } \\
(\mathrm{mmol} / \mathrm{L})\end{array}$ & $117.64 \pm 10.51$ & $117.02 \pm 10.15$ & $119.28 \pm 10.00$ & $122.58 \pm 6.85$ & $123.68 \pm 3.37$ \\
\hline $\begin{array}{l}\text { Fluid deficit } \\
(\mathrm{mL})\end{array}$ & $\begin{array}{l}2153.10 \pm 1059.27 \\
(1060-4500)\end{array}$ & $\begin{array}{l}2172.10 \pm 997.55 \\
(1220-4400)\end{array}$ & $\begin{array}{l}1992.20 \pm 962.96 \\
(1000-3800)\end{array}$ & $\begin{array}{l}1558.30 \pm 681.57 \\
(1110-2600)\end{array}$ & $\begin{array}{l}1507.50 \pm 341.41 \\
(1070-1850)\end{array}$ \\
\hline
\end{tabular}




\begin{tabular}{llllll}
\hline $\begin{array}{l}\text { Type of } \\
\text { procedure }\end{array}$ & TCRF & TCRA & $\begin{array}{l}\text { RPOC } \\
\text { removal }\end{array}$ & HSR & TCRE \\
\hline $\begin{array}{l}\text { Surgical time } \\
\begin{array}{l}\text { (minute) } \\
\text { No. of clinical } \\
\text { consequence }\end{array}\end{array}$ & $67.25 \pm 33.35$ & $68.07 \pm 49.65$ & $45.56 \pm 24.93$ & $59.00 \pm 50.44$ & $81.25 \pm 69.93$ \\
\hline
\end{tabular}

Table 2. Sign and symptom presented in different fluid deficit range

\begin{tabular}{|c|c|c|c|c|}
\hline Fluid Deficit & No. of Procedure & $\begin{array}{l}\text { No. of Case With } \\
\text { Clinical Symptom }\end{array}$ & $\begin{array}{l}\text { No. of Case with } \\
\text { Clinical Sign }\end{array}$ & $\begin{array}{l}\text { No. of Case } \\
\text { Without Clinical } \\
\text { Consequence }\end{array}$ \\
\hline ¿2500ml & $\begin{array}{l}\mathrm{N}=10 \text { Myomectomy } \\
3 \text { Adhesiolysis } 4 \\
\text { RCOP } 2 \text { HSR } 1\end{array}$ & $\mathrm{~N}=2$ Coughing 2 & $\begin{array}{l}\mathrm{N}=5 \text { Hypotension } 2 \\
\text { Hypoxemia } 2 \\
\text { Tachycardia } 1 \\
\text { Laryngeal Edema } 1 \\
\text { Pulmonary Edema } 1\end{array}$ & $\mathrm{~N}=4$ \\
\hline $1500-2500 \mathrm{ml}$ & $\begin{array}{l}\mathrm{N}=21 \text { Myomectomy } \\
8 \text { Adhesiolysis } 6 \\
\text { RCOP } 4 \text { HSR } 1 \\
\text { TCRE } 2\end{array}$ & $\begin{array}{l}\mathrm{N}=4 \text { Coughing } 1 \\
\text { Nausea } 1 \text { Vomiting } \\
2\end{array}$ & $\begin{array}{l}\mathrm{N}=4 \text { Hypotension } 1 \\
\text { Hypoxemia } 3 \\
\text { Pulmonary Edema } 4\end{array}$ & $\mathrm{~N}=13$ \\
\hline $1000-1500 \mathrm{ml}$ & $\begin{array}{l}\mathrm{N}=18 \text { Myomectomy } \\
5 \text { Adhesiolysis } 4 \\
\text { RCOP } 3 \text { HSR } 4 \\
\text { TCRE } 2\end{array}$ & $\mathrm{~N}=2$ Vomiting 2 & $\begin{array}{l}\mathrm{N}=2 \text { Hypoxemia } 1 \\
\text { Bulbar Edema } 1\end{array}$ & $\mathrm{~N}=14$ \\
\hline
\end{tabular}

Table 3 Sign and symptom presented in different serum sodium range

\begin{tabular}{lllll}
\hline Serum Sodium & No of Procedure & No. of Case With Clinical Symptom & No. of Case with Clinical Sign & No. of Case V \\
\hline$[?] 100 \mathrm{mmol} / \mathrm{L}$ & $\mathrm{N}=3$ & $\mathrm{~N}=0$ & $\mathrm{~N}=3$ & $\mathrm{~N}=0$ \\
$100-110 \mathrm{mmol} / \mathrm{L}$ & $\mathrm{N}=6$ & $\mathrm{~N}=2$ & $\mathrm{~N}=2$ & $\mathrm{~N}=3$ \\
$110-120 \mathrm{mmol} / \mathrm{L}$ & $\mathrm{N}=11$ & $\mathrm{~N}=2$ & $\mathrm{~N}=2$ & $\mathrm{~N}=7$ \\
$120-130 \mathrm{mmol} / \mathrm{L}$ & $\mathrm{N}=29$ & $\mathrm{~N}=4$ & $\mathrm{~N}=4$ & $\mathrm{~N}=21$ \\
\hline
\end{tabular}

